\title{
Pengaruh Umur Pemotongan Terhadap Produksi dan Kualitas Nutrisi Tanaman Indigofera (Indigofera Sp)
}

\author{
Erlis Setiyaningrum, I Nyoman Kaca, Ni Ketut Etty Suwitari \\ Program studi Peternakan Fakultas Pertanian Universitas Warmadewa \\ Email: erlisning@yahoo.com
}

\begin{abstract}
This study was held at BPTU-HPT Denpasar which located in Pangyangan Village, Pekutatan Sub-district, Jembrana Regency conducted from January 18, 2017 - April 18, 2017. Analysis of nutritional content was performed at the Laboratory of the Agriculture Faculty of Warmadewa University and the Udayana University Faculty of Animal Husbandry Laboratory. The purpose of this study to determine the effect of cutting age on production and quality of nutrition Indigofera sp.The Method of this study did use on Complete Randomized Design (CRD) which consisted of 3 groups and 4 treatment of cutting age. The treatments in this study were P1 (45 days of Cutting Age), P2 (60 days of cutting age), P3 (75 days of cutting age), and P4 (90 days of cutting age). The results showed that the effect of different cutting age gave a most real effect $(P<0.01)$ on the production of dry weight, coarse fiber, crude protein and dry matter content, meanwhile different of cutting age gave significantly affect $(P<0,05)$ to ash content.The study suggests that Indigofera sp was able to provide better nutrition as animal forages at 60 days of cutting age.
\end{abstract}

Keywords: Indigofera sp, cutting age, dry weight, nutrient content

\section{Pendahuluan}

Ketersediaan pakan untuk ternak ruminansia khususnya hijauan merupakan masalah yang masih sulit di Indonesia. Jenis hijauan yang dapat diberikan untuk ternak selain rumput-rumputan yaitu tanaman leguminosa yang mempunyai kandungan protein cukup tinggi dibandingkan dengan jenis rumputrumputan. Tanaman Leguminosa pohon telah dikenal memiliki potensi sebagai sumber pakan berkualitas tinggi, terutama selama musim kering saat ketersediaan hijauan rumput menurun tajam, salah satu jenis tanaman leguminosa pohon yang dapat dipakai sebagai pakan ternak adalah Indigofera sp.

Indigofera sp sangat baik dimanfaatkan sebagai hijauan pakan ternak karena memiliki kandungan protein yang tinggi, toleran terhadap musim kering, genangan air dan tahan terhadap salinitas (Hassen et al., 2007). Ketersediaan Indigofera sp yang tinggi dapat dicapai dengan manajemen pengelolaan yang meliputi upaya perbaikan pengolahan lahan, cara tanam, pemupukan, pengendalian terhadap gulma, pengairan, dan pengaturan umur pemotongan. Pengaturan umur pemotongan sangat mempengaruhi kualitas dan produksi tanaman. Semakin lambat suatu tanaman dipotong, kemungkinan produksi akan meningkat, kandungan serat kasar akan meningkat dan sebaliknya nilai gizi semakin menurun karena banyak zat makanan yang hilang untuk di ubah menjadi buah atau biji. Demikian pula sebaliknya apabila pemotongan dilakukan lebih awal atau dilakukan dalam interval pemotongan yang pendek maka kemungkinan yang terjadi kandungan protein tinggi, kandungan air juga tinggi, sedangkan produksinya rendah. Oleh karena itu perlu dipikirkan waktu pemotongan yang optimal sehingga nilai gizi hijauan tersebut cukup tinggi dan dapat memenuhi kebutuhan ternak.

\section{Bahan dan Metode}

Penelitian ini dilaksanakan di BPTU-HPT Denpasar yang berlokasi di Desa Pangyangan, Kecamatan Pekutatan, Jembrana. Daerah tempat dilakukannya penelitian ini beriklim tropis muson dengan curah 
Pengaruh Umur Pemotongan Terhadap Produksi dan Kualitas Nutrisi Tanaman Indigofera (Indigofera Sp)

hujan $1930 \mathrm{~mm}$ per tahun dengan ketinggian $100 \mathrm{~m}$ dpl dan suhu rata-rata per tahunan adalah $26,3{ }^{\circ} \mathrm{C}$. Penelitian ini dilakukan dari tanggal 18 Januari sampai dengan 18 April 2017. Analisis kandungan nutrisi Indigofera sp dilaksanakan di Laboratorium Fakultas Pertanian Universitas Warmadewa dan di Laboratorium Fakultas Peternakan Universitas Udayana.

Materi yang digunakan pada penelitian ini ialah tanaman Indigofera sp yang dibudidayakan di BPTU-HPT Denpasar. Tanaman Indigofera sp yang dipakai sudah berumur satu tahun tapi belum pernah di pangkas sebelumnya dan dipotong seragam dengam ketinggian $60 \mathrm{~cm}$. Jarak tanam antar pohon 1,5 m x $1,5 \mathrm{~m}$ pada lahan seluas $132 \mathrm{~m}^{2}$ dengan sistem tanaman tunggal. Selama penelitian tanaman yang dipakai untuk penelitian tidak mendapatkan perlakuan penyiraman dan pemupukan. Metode yang digunakan pada penelitian ini adalah metode percobaan dengan menggunakan Rancangan Acak Kelompok (RAK) yang terdiri dari 3 kelompok dan 4 perlakuan umur pemotongan. Perlakuan penelitian ini adalah: P1 (Umur Pemotongan 45 hari), P2 (Umur Pemotongan 60 hari), P3 (Umur Pemotongan 75 hari), dan P4 (Umur Pemotongan 90 hari).

\section{Hasil dan Pembahasan}

Berdasarkan hasil analisa statistik pada pengaruh umur pemotongan terhadap produksi berat kering, serat kasar, kadar abu, protein kasar dan kandungan bahan kering pada tanaman Indigofera sp dapat dilihat pada Tabel 1.

Tabel 1

Rata - Rata Produksi dan Kualitas Nutrisi Tanaman Indigofera sp pada Umur Pemotongan yang Berbeda

\begin{tabular}{cccccc}
\hline \multirow{2}{*}{ Variabel } & \multicolumn{4}{c}{ Perlakuan } & \multirow{2}{*}{ SEM $^{2)}$} \\
\cline { 2 - 5 } & $\mathbf{P}_{\mathbf{1}}$ & $\mathbf{P}_{\mathbf{2}}$ & $\mathbf{P}_{\mathbf{3}}$ & $\mathbf{P}_{\mathbf{4}}$ & \\
\hline Produksi Berat Kering (kg/pohon/th) & $150.30^{\mathrm{d} 3)}$ & $326.90^{\mathrm{c}}$ & $533.41^{\mathrm{b}}$ & $802.07^{\mathrm{a}}$ & 46.657 \\
Serat Kasar (\%) & $19.22^{\mathrm{c}}$ & $20.20^{\mathrm{bc}}$ & $21.05^{\mathrm{b}}$ & $23.62^{\mathrm{a}}$ & 0.267 \\
Kadar Abu (\%) & $10.80^{\mathrm{b}}$ & $11.32^{\mathrm{b}}$ & $12.84^{\mathrm{a}}$ & $12.59^{\mathrm{a}}$ & 0.341 \\
Protein Kasar (\%) & $26.22^{\mathrm{a}}$ & $24.67^{\mathrm{b}}$ & $23.01^{\mathrm{cd}}$ & $21.54^{\mathrm{d}}$ & 0.428 \\
Kandungan Bahan Kering (\%) & $23.51^{\mathrm{b}}$ & $24.89^{\mathrm{b}}$ & $26.99^{\mathrm{ab}}$ & $30.98^{\mathrm{a}}$ & 1.758 \\
\hline
\end{tabular}

Keterangan :

1. Umur pemotongan $\mathrm{P}_{1} 45$ hari, $\mathrm{P}_{2} 60$ hari, $\mathrm{P}_{3} 75$ hari dan $\mathrm{P}_{4} 90$ hari

2. SEM (Standard Error of The Threatmend Means)

3. Huruf superskrip dibelakang angka yang berbeda pada kolom yang sama

menunjukkan berbeda nyata $(\mathrm{P}<0.05)$ sampai sangat nyata $(\mathrm{P}<0.01)$.

Dari hasil penelitian pengaruh umur pemotongan terhadap produksi berat kering, serat kasar, kadar abu, protein kasar serta kandungan bahan kering tanaman Indigofera sp memperoleh perbedaan yang sangat nyata $(\mathrm{P}<0.01)$. Tabel 1 menunjukkan produksi berat kering tertinggi yaitu pada umur pemotongan 90 hari $\left(\mathrm{P}_{4}\right)$ di ikuti dengan umur pemotongan 75 hari $\left(\mathrm{P}_{3}\right), 60$ hari $\left(\mathrm{P}_{2}\right)$, dan 45 hari $\left(\mathrm{P}_{1}\right)$. Givens et al. (2000) menyatakan bahwa semakin tinggi umur pemotongan maka komponen dinding sel suatu hijauan akan semakin tinggi. Komponen dinding sel yang semakin tinggi mengakibatkan kandungan berat kering juga semakin tinggi. Hal ini yang menyebabkan umur pemotongan 90 hari $\left(\mathrm{P}_{4}\right)$ menghasilkan produksi berat kering tertinggi dibandingkan umur pemotongan lainnya. Hal ini sesuai dengan pendapat Rochiman dkk. (2000) yang menyebutkan bahwa interval pemotongan yang panjang memberikan produksi kumulatif berat kering lebih tinggi daripada interval pemotongan yang pendek.

Pengaruh berbagai umur pemotongan terhadap kandungan serat kasar dapat dilihat pada Tabel 1. 
Berdasarkan grafik tersebut dapat dilihat bahwa kandungan serat kasar tanaman Indigofera sp dari tertinggi sampai terendah berturut-turut yaitu $\mathrm{P}_{4} \mathrm{P}_{3}, \mathrm{P}_{2}$, dan $\mathrm{P}_{1}$. Umur pemotongan 90 hari $\left(\mathrm{P}_{4}\right)$ memiliki kandungan serat kasar yang tertinggi, ini disebabkan oleh umur tanaman yang semakin tua mempunyai kandungan dinding sel yang tinggi, hal ini didukung oleh penelitian dari Djuned dkk. (2005) yang menyatakan bahwa kandungan fraksi serat pada tanaman murbei terus meningkat seiring dengan lamanya umur pemotongan. Oleh karena itu, semakin tua tanaman maka kandungan seratnya semakin tinggi. Kandungan serat kasar Indigofera sp pada penelitian ini berkisar 19,22-23,62\%. Sedangkan kandungan serat kasar Indigofera sp menurut Hassen et al. (2007) sebesar 15,25-27,97\%; Akbarillah dkk. (2002) melaporkan kandungan serat kasar sebesar 19,80-24,00\%; Tangendjaja (1991) sebesar 22,10 $-26,00 \%$.

Kandungan kadar abu berbagai umur pemotongan dapat dilihat pada Tabel 1. Dari hasil statistik diperoleh perlakuan $\mathrm{P}_{3}$ memberikan hasil tertinggi dibandingkan perlakuan $\mathrm{P}_{2}$ dan $\mathrm{P}_{1}$ dan $\mathrm{P}_{4}$, kadar abu mengalami peningkatan seiring dengan umur pemotongan tanaman. Menurut Zhao et al. (2009), kandungan mineral atau abu sangat dipengaruhi oleh kondisi air tanah dimana kecukupan air akan menurunkan karbohidrat terlarut dan meningkatkan konsentrasi mineral, sebaliknya pada kondisi kering, kandungan karbohidrat terlarut meningkat dan konsentrasi mineral menurun. Bogale \& Tesfaye (2011), melaporkan bahwa kandungan abu secara signifikan sangat berhubungan dengan kondisi iklim, seperti halnya pengaruh defisit air. Stres air berat menurunkan kandungan abu secara signifikan pada fase vegetatif dan pengisian polong. Menurut Clavero et al. (2001), frekuensi pemangkasan berpengaruh terhadap konsentrasi mineral yang terkandung dalam tanaman.

Hasil penelitian pengaruh berbagai umur pemotongan terhadap kandungan protein kasar dapat dilihat pada Tabel 1, disebutkan hasil tertinggi pada umur pemotongan $\mathrm{P}_{1}$ (45 hari) sedangkan hasil terendah pada pemotongan $\mathrm{P}_{4}$ (90 hari). Kandungan protein kasar menurun seiring dengan semakin tua umur tanaman. Semakin tua umur tanaman maka produksi batang dan bunga meningkat, tetapi produksi daun menurun hal ini yang mempengaruhi kandungan protein tanaman tersebut. Menurut Mansyur dkk. (2005), jika interval pemotongan diperpanjang akan terjadi penurunan kandungan protein kasar. Penurunan kadar protein kasar selain karena umur tanaman juga disebabkan oleh penurunan proporsi helai daun dengan kelopak daun dan batang, dimana pada helai daun mempunyai kandungan protein yang lebih tinggi dibandingkan dengan bagian kelopak daun dan batang. Kandungan protein kasar Indigofera sp pada penelitian ini berkisar 21,54 - 26,22\%. Menurut hasil penelitian ini dan hasil penelitian yang lain menunjukkan bahwa Indigofera sp mengandung protein yang sangat tinggi.

Hasil penelitian pengaruh berbagai umur pemotongan terhadap kandungan bahan kering dapat dilihat pada Tabel 1, memperlihatkan bahwa rataan kandungan bahan kering Indigofera sp paling rendah adalah pemotongan $\mathrm{P}_{1}$ dan kandungan bahan kering tertinggi pada pemotongan $\mathrm{P}_{4}$. Umur pemotongan $\mathrm{P}_{1}$ memiliki kandungan bahan kering yang rendah, hal ini disebabkan karena tanaman yang masih muda mempunyai sel aktif untuk melakukan proses pembelahan sel maupun pembentukan jaringan. Tanaman yang usia tua terjadi penebalan dinding sel yang mengakibatkan kandungan bahan kering meningkat. Semakin tinggi umur tanaman maka komponen dinding sel suatu hijauan akan semakin tinggi (Djuned dkk., 2005). Mansyur dkk. (2005) menambahkan adanya kecenderungan perubahan produksi segar dan kering seiring dengan lama umur pemotongan dikarenakan proporsi bahan kering yang dikandung oleh suatu tanaman berubah seiring dengan umur tanaman. Semakin tua tanaman maka akan lebih sedikit kandungan airnya dan proporsi dinding selnya lebih tinggi dibandingkan dengan isi sel. Kandungan dinding sel yang semakin tinggi, maka tanaman tersebut akan lebih banyak mengandung bahan kering. 


\section{Kesimpulan}

Berdasarkan hasil penelitian maka dapat disimpulkan bahwa umur pemotongan yang berbeda terhadap tanaman Indigofera sp dapat mempengaruhi produksi berat kering, serat kasar, kadar abu, protein kasar serta kandungan bahan kering. Pada umur pemotongan 90 hari diperoleh produksi berat kering, serat kasar, kadar abu dan kandungan bahan kering yang tinggi tetapi kandungan protein kasar akan semakin rendah.

Produksi hijauan Indigofera sp mempunyai kualitas yang baik dengan kandungan protein kasar yang tinggi serta serat kasar yang relatif rendah, maka tanaman Indigofera sp bisa digunakan sebagai pakan ternak. Berdasarkan penelitian ini disarankan pemotongan Indigofera sp sebagai pakan ternak dilakukan pada umur 60 hari.

\section{Referensi}

Akbarillah, T., Kaharuddin, D., \& Kusisiyah (2002). Kajian tepung daun Indigofera sebagai suplemen pakan terhadap produksi dan kualitas telur. Laporan penelitian. Lembaga penelitian Universitas Bengkulu.

Bogale, A, \& Tesfaye, K. (2011). Relationship between Kernell ash content, water use efficiency and yield in Durum Wheat under water deficit induced at different growth stages. Afr J Basic Appl Sci. 3:80-86.

Clavero, T, Miquelena, E., \& Rodríguez, P.A. (2001). Mineral contents of Acacia mangium Wild under defoliation conditions. Rev Fac Agron. 18:217-221.

Djuned, H., Mansyur, \& Wijayanti, H.B. (2005). Pengaruh umur pemotongan terhadap kandungan fraksi serat hijauan murbei (Morus indica L. Var. Kanva-2). Seminar Nasional Teknologi Peternakan dan Veteriner.

Givens. D.I., Owen, E., Oxford, R.F.E., \& Omed, H.M. (2000). Forage evaluation in ruminant nutrition. CABI Publishing Wallingford U.K.

Hassen, A., Rethman, N.F.G., Van Niekerk, W.A., \& Tjelele, T.J. (2007). Influence of season/year and species on chemical composition and in vitro digestibility of five Indogofera accessions. Anim. Feed Sci. Technol. $136: 312-322$.

Mansyur, Djuned, H., Dhalika, T., Hardjosoewignyo, S., \& Abdullah, L. (2005). Pengaruh interval pemotongan dan inveksi gulma Chromolaena odorata terhadap produksi dan kualitas rumput Brachiaria humidicola. Media Peternakan.

Rochiman K., Harjosoewignyo, S., \& Surkati, A. (2000). Pengaruh pupuk kandang, urea, dan interval pemotongan terhadap produksi serta ketahanan Stylosanthes guyanensis. Bul. Agr. Vol XIV No. 2.

Tangendjaja, B. (1991). Komposisi dan Sifat Kimia Daun Gamal. Balai Penelitian Ternak, Bogor.

Zhao, C.X, HeMing, R., Wang, Z., Wang, \& Lin-Qi, Y.F. (2009). Effects of different water availability at postanthesis stage on grain Nutrition and quality in strong-gluten winter wheat. C.R. Biologies. 332:759-764. 